Позняковська Н. М., к.е.н., доцент (Національний університет водного господарства та природокористування, м. Рівне)

\title{
ПРОФЕСІЙНА БУХГАЛТЕРСЬКА ОСВІТА ЗА МІЖНАРОДНИМИ СТАНДАРТАМИ
}

У статті розглядаються питання навчання професійних бухгалтерів за Міжнародними стандартами освіти та основні положення бухгалтерської освіти за національним законодавством.

Ключові слова: Міжнародні стандарти освіти, професійний бухгалтер, професійна компетентність, технічна компетентність, професійні навики, професійні цінності, етичні принципи і підходи.

Постановка проблеми. Реформування бухгалтерського обліку відповідно до міжнародних стандартів, створення нової нормативної бази бухгалтерського обліку потребує нової якості бухгалтерської професії. Остання редакція основного «бухгалтерського» закону наблизила правила національного бухгалтерського обліку і звітності 3 міжнародними стандартами та законодавством Євросоюзу: зміни у принципах бухгалтерського обліку і фінансової звітності; нова класифікація підприємств на мікро-, малі, середні і великі підприємства; нові групи підприємств, для яких встановлюються підвищені вимоги щодо ведення бухгалтерського обліку, складання та оприлюднення фінансової звітності; введення нових звітів з нефінансовою інформацією; зміни у підходах до розкриття суб'єктами господарювання фінансової інформації. Оновленим Законом «Про бухгалтерський облік та фінансову звітність і Україні» [1] зобов'язано певні підприємства, які складали фінансову звітність та консолідовану фінансову звітність за Міжнародними стандартами, забезпечити ведення бухгалтерського обліку за Міжнародними стандартами після подання першої фінансової звітності. 32018 року запроваджена таксономія фінансових звітів за Міжнародними стандартами. Виконання задач високого рівня потребує від фахівця професійних знань, вмінь і навичок, окрім того - й володіння етичними принципами і нормами. 3 іншого боку, глобалізаційні процеси вимагають врахування у підготовці фахівців вимог до професії за світовими стандартами освіти.

Аналіз останніх досліджень та публікацій. Стан, формування та вдосконалення вітчизняної бухгалтерської освіти знайшли відображення в працях вчених: М. Білухи, П. Безруких, Ф. Бутинця, С. Голова, С. Зубілевич, Л. Кіндрацької, Г. Кірейцева, В. Костюченко, А. Пилипе- 
нка, В. Пархоменка, Я. Соколова, В. Сопка, М. Чумаченка, Л. Чижевської та ін. Однак, залишаються актуальними питання реформування вітчизняної бухгалтерської освіти, дослідження їх відповідності до Міжнародних стандартів освіти.

Метою статті $€$ вивчення положень Міжнародних стандартів освіти (МСО) задля вдосконалення бухгалтерської освіти України, враховуючи реформування вітчизняної освіти, і професійної освіти бухгалтерів зокрема.

Виклад основного матеріалу. Міжнародні стандарти освіти професійних бухгалтерів розроблені Комітетом з МСО Міжнароднох Федерації бухгалтерів. Впровадження та застосування Міжнародних стандартів освіти [2] має за мету усунення відмінностей від вимог, що існують у світі, до ролі професійного бухгалтера; сприяння росту глобальної мобільності професійних бухгалтерів та визнання світовою спільнотою основних положень у сфері професійної бухгалтерської освіти. Термін «професійний бухгалтер» наводиться у Міжнародних стандартах освіти, Міжнародних стандартах бухгалтерського обліку в державному секторі Міжнародних стандартах контролю якості, аудиту, огляду, іншого надання впевненості та супутніх послуг. Національне законодавство не містить визначення терміну професійного бухгалтера. На думку професора С. Зубілевич [3], це особа, яка завдяки формальній освіті та практичному досвіду, $є$ експертом у сфері бухгалтерського обліку, що демонструє і підтримує компетентність, відповідає кодексу етики, дотримується високих професійних стандартів і діяльність якої регулюється через професійну організацію бухгалтерів або інший механізм регулювання.

Міжнародні стандарти освіти містять вимоги до програм професійної бухгалтерської освіти (таблиця).

Таблиця

Вимоги до програм професійної бухгалтерської освіти

\begin{tabular}{|l|l|c|}
\hline \multicolumn{1}{|c|}{ Рівень освіти } & \multicolumn{1}{|c|}{ Найменування } & MCO \\
\hline Первинна професійна освіта & Технічна компетентність & IES 2 \\
\hline Первинна професійна освіта & Професійні навики & IES 3 \\
\hline Первинна професійна освіта & $\begin{array}{l}\text { Професійні цінності, етичні } \\
\text { принципи і підходи }\end{array}$ & IES 4 \\
\hline Первинна професійна освіта & Практичний досвід & IES 5 \\
\hline Первинна професійна освіта & $\begin{array}{l}\text { Оцінка професійної компе- } \\
\text { тентності }\end{array}$ & IES 6 \\
\hline
\end{tabular}

Професійна компетентність за МСО не обмежується знаннями принципів, стандартів, понять і процедур, а є застосуванням на прак- 
тиці технічної компетентності, професійних навичок, професійних цінностей, етичних принципів і норм (рис. 1).

\section{Професійна компетентність}

\section{Технічна компетентність}

\section{Професійні навички}

\section{Професійні пінності, етичні принципи і норми}

Рис. 1. Професійна компетентність за Міжнародними стандартами освіти

Під технічною компетентністю розуміють здатність виконувати робочі функції відповідно до встановленого стандарту з урахуванням реальних робочих умов. MCO (IES) 2 визначає рівень технічної компетентності, яку особа, що прагне отримати статус професійного бухгалтера, повинна продемонструвати наприкінці початкового професійного розвитку. Стандартом визначений основний перелік сфер компетентностей, та рівень компетентності, яким повинен володіти майбутній професійний бухгалтер за цими сферами.

До переліку дисциплін входять:

мікро- і макроекономіка,

фінансовий облік,

управлінський облік,

фінанси і фінансовий менеджмент,

оподаткування,

аудит,

нагляд, управління ризиками і внутрішній контроль,

господарське право,

інформаційні технології,

бізнес- і організаційне середовище,

бізнес стратегія і менеджмент.

Умови застосування, зміст і глибина знань та розуміння дисциплін встановлено стандартом для базового, середнього і високого рівнів технічної компетентності (рис. 2). 

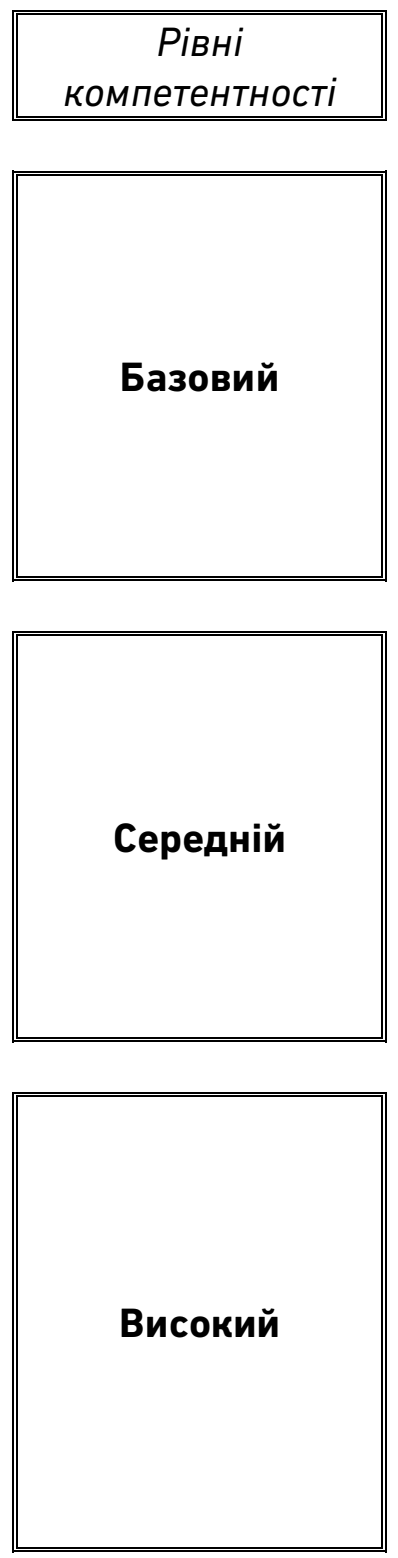

\begin{tabular}{|c|c|}
\hline Опис & $\begin{array}{c}\text { Основні } \\
\text { характеристики }\end{array}$ \\
\hline
\end{tabular}

В ситуаціях, які хара- Виконання завдань ктеризуються низьким рівнем невизначеності та складності за допомогою професійних навичок; рішення простих проблем; переадресування складних задач керівникам тощо

\begin{tabular}{||l||l||}
\hline \hline В ситуаціях, які хара- & Самостійне засто- \\
ктеризуються серед- & сування і аналіз ба- \\
ній (помірним) рівнем & зових принципів і \\
невизначеності та & теоретичних основ; \\
складності & надання i \\
& роз'яснення інфор- \\
& мації зацікавленим \\
\hline
\end{tabular}

\begin{tabular}{||l||l||}
\hline В ситуаціях, які хара- & Формування про- \\
ктеризуються висо- & фесійних суджень; \\
ким рівнем невизна- & оцінка, вивчення і \\
ченості та складності & рішення складних \\
& проблем; подання і \\
роз'яснення інфор- \\
мації широкому ко- \\
лу зацікавлених \\
сторін \\
\hline
\end{tabular}

Рис. 2. Рівні технічної компетентності

Професійні навички є другим компонентом компетентності. МСО (IES) 3 визначає їх перелік та рівень володіння, який повинен бути продемонстрований наприкінці початкового професійного розвитку.

До професійних відносять:

Інтелектуальні навички - здатність вирішувати проблеми, приймати рішення і формулювати професійне судження.

Навички міжособистісного спілкування і комунікації - здатність працювати і ефективно взяємодіяти з іншими. 
Персональні - особисте ставлення та поведінка.

Організаційні навички - здатність працювати з організацією або всередині ії для отримання оптимальних результатів [2].

Дотримання професійної етики є невід'ємною рисою професійного бухгалтера (MCO IES 4). Початковий професійний розвиток передбачає оволодіння фундаментальними етичними принципами: цілісністю, об'єктивністю, професійною компетентністю і ретельністю, конфіденційністю, професійною поведінкою.

У стандарті виділені три сфери компетентності -

професійний скептицизм та професійне судження,

етичні принципи та

дія в суспільних інтересах, з яких ідентифіковані результати навчання [2].

MCO (IES) 5 визначає вимоги до практичного досвіду, який повинен бути отриманим до завершення початкового професійного розвитку. Досвід має бути достатнім, щоб надати можливість продемонструвати компетентності, навички, засвоєння професійних цінностей, етики та поведінки, які відповідають ролі професійного бухгалтера. Частина досвіду може бути отримана під час навчання за програмами. Стандарт містить вимогу щодо надбання практичного досвіду під керівництвом професійного фахівця, що має бути зафіксовано у єдиному форматі.

Форми оцінювання розглядає MCO (IES) 6: єдиний екзамен 3 комплексу навчальних дисциплін; екзамен з комплексу навчальних дисциплін певної сфери компетентності; серія екзаменів з окремих навчальних дисциплін.

Професійну компетентність можна оцінити за результатами письмових іспитів; усних іспитів; тестування; опитувань роботодавців; записів про діяльність.

Отже, складовими первинної професійної бухгалтерської освіти за МСО є професійна бухгалтерська освіта, практичний досвід і оцінка. Частки цих складових повинні визначатися правилами Міжнародної Федерації бухгалтерів, національним законодавством, вимогами регуляторів, i, що особливо важливо - суспільним очікуванням.

Національне законодавство - Закон про вищу освіту [4] - визначає компетентність як динамічну комбінацію знань, вмінь і практичних навичок, способів мислення, професійних, світоглядних і громадянських якостей, морально-етичних цінностей, яка робить особу здатною успішно здійснювати професійну та подальшу навчальну діяльність $\mathrm{i} \epsilon$ результатом навчання на певному рівні вищої освіти.

В Україні Стандарт вищої освіти встановлює сукупність вимог до змісту та результатів освітньої діяльності закладів вищої освіти і на- 
укових установ за кожним рівнем вищої освіти в межах кожної спеціальності. Стандарт розробляється відповідно до Національної рамки кваліфікацій і використовуються для визначення та оцінювання якості змісту та результатів освітньої діяльності закладів вищої освіти (наукових установ). Стандарт вищої освіти визначає такі вимоги до освітньої програми:

обсяг кредитів ЄКТС, необхідний для здобуття відповідного ступеня вищої освіти;

перелік компетентностей випускника;

нормативний зміст підготовки здобувачів вищої освіти, сформульований у термінах результатів навчання;

форми атестації здобувачів вищої освіти;

вимоги до наявності системи внутрішнього забезпечення якості вищої освіти;

вимоги професійних стандартів (у разі їх наявності).

Заклад вищої освіти на підставі відповідної освітньої програми за кожною спеціальністю розробляє навчальний план, який визначає перелік та обсяг навчальних дисциплін у кредитах ЄКТС, послідовність вивчення дисциплін, форми проведення навчальних занять та їх обсяг, графік навчального процесу, форми поточного і підсумкового контролю.

На основі навчального плану у визначеному закладом вищої освіти порядку розробляються та затверджуються індивідуальні навчальні плани студентів, що мають містити, у тому числі, обрані здобувачами вищої освіти навчальні дисципліни.

Для забезпечення ринку праці кваліфікованими бухгалтерами і аудиторами провідний заклад вищої освіти - Національний університет водного господарства та природокористування - готує здобувачів першого (бакалаврського) і другого (магістерського) рівнів освіти на підставі Тимчасових стандартів вищої освіти за галуззю знань 07 «Управління та адміністрування» спеціальністю 071 «Облік і оподаткування» [5; 6]. На підставі Тимчасових стандартів вищої освіти розроблені відповідно освітньо-професійні програми вищої освіти підготовки бакалавра і магістра.

У складі компетентностей випускника за спеціальністю «Облік і оподаткування» визначені інтегральні, загальні і спеціальні (фахові) компетентності. У Тимчасовому стандарті вказано програмні результати навчання $[5 ; 6]$.

Освітньо-професійна програма вищої освіти містить Перелік компонент освітньо-професійної програми, у якому дисципліни розподілені за циклом загальної і професійної підготовки, та структурно- 
логічну схему підготовки здобувачів вищої освіти.

Перелік та обсяг навчальних дисциплін, форми проведення занять, поточного та підсумкового контролю встановлює навчальний план спеціальності «Облік і оподаткування». На сьогодні здобувач вищої освіти повинен має право вибору 25\% дисциплін навчального плану. Окрім обовязкових і вибіркових дисциплін, навчальним планом передбачені навчальна і виробничі практики. На відміну від світових стандартів вимоги до набуття здобувачами на практиках необхідних навичок носять дещо формальний характер. За національним законодавством набуття практичного досвіду до завершення початкового професійного розвитку не є обов'язковою вимогою для отримання здобувачем рівня вищої освіти.

Міністерством освіти і науки України наприкінці поточного року затверджений Стандарт вищої освіти за спеціальністю 071 «Облік і оподаткування» для першого (бакалаврського) рівня вищої освіти [7]. Стандарт вказує компетентності: інтегральну, загальні і спеціальні (фахові) компетентності. Під інтегральною компетентністю розуміють здатність випускника першого (бакалаврського) рівня вищої освіти розв'язувати складні спеціалізовані задачі та практичні проблеми під час професійної діяльності у ситуаціях, що характеризуються комплексністю і невизначеністю умов, що відповідає високому рівню професійної компетентності за МСО. Вочевидь, вимоги до випускника магістерського рівня освіти мають бути вищими.

Висновки. Отже, положення національного законодавства 3 освіти дещо відрізняються від рекомендацій Міжнародних стандартів бухгалтерської освіти. На відміну від кращого світового досвіду відчизняні професійні організації не мають визнаних законодавством повноважень у сфері освіти і надання кваліфікації. Проблеми удосконалення якості освіти, посилення практичної підготовки здобувачів вищої освіти доцільно розв'язувати в контексті імплементації вітчизняного законодавства до Міжнародних стандартів світи. Наближення змісту освітньо-професійних програм до МСО надасть можливість скоротити тривалість входження у професію.

1. Про внесення змін до Закону України «Про бухгалтерський облік та фінансову звітність в Україні» щодо удосконалення деяких положень» : Закон України від 05.10.2017 р. № 2164-VIII. URL: http://zakon5.rada.gov.ua/laws/show/2164-19 (дата звернення: 15.01.2019). 2. Handbook of International Education Pronouncements 2017. URL: https://www.ifac.org/publications-resources/2017-handbook-internationaleducation-pronouncements (дата звернення: 15.01.2019). 3. Зубілевич С. Міжнародні стандарти освіти як основа єдиної національної програми професійної сертифікації бухгалтерів України. Бухгалтерський облік $і$ аудит. 
2014. № 5. С. 8-15. 4. Про вищу освіту : Закон України від 01.07.2014 року 1556-VII у ред. від 25.07.2018 року. URL: http://zakon.rada.gov.ua/laws/show/1556-18 (дата звернення: 15.01.2019). 5. Тимчасовий стандарт вищої освіти першого (бакалаврського) рівня за галуззю знань 07 «Управління та адміністрування», спеціальність 071 «0блік і оподаткування», затв. протоколом Вченої Ради НУВГП № 3 від 25.03.2016 р. 6. Тимчасовий стандарт вищої освіти другого (магістерського) рівня за галуззю знань 07 «Управління та адміністрування», спеціальність 071 «Облік і оподаткування», затв. протоколом Вченої Ради НУВГП № 3 від 25.03.2016 р. 7. Про затвердження стандарту вищої освіти за спеціальністю 071 «Облік і оподаткування» для першого (бакалаврського) рівня вищої освіти : наказ Міністерства освіти і науки України № 1260 від 19.11.2018р.

\section{REFERENCES:}

1. Pro vnesennia zmin do Zakonu Ukrainy «Pro bukhhalterskyi oblik ta finansovu zvitnist $v$ Ukraini» shchodo udoskonalennia deiakykh polozhen» : Zakon Ukrainy vid 05.10.2017 r. № 2164-VIII. URL: http://zakon5.rada.gov.ua/laws/show/2164-19 (data zvernennia: 15.01.2019). 2. Handbook of International Education Pronouncements 2017. URL: https://www.ifac.org/publications-resources/2017-handbook-internationaleducation-pronouncements (data zvernennia: 15.01.2019). 3. Zubilevych S. Mizhnarodni standarty osvity yak osnova yedynoi natsionalnoi prohramy profesiinoi sertyfikatsii bukhhalteriv Ukrainy. Bukhhalterskyi oblik $i$ audyt. 2014. № 5. S. 8-15. 4. Pro vyshchu osvitu : Zakon Ukrainy vid 01.07.2014 roku 1556VII u red. vid 25.07.2018 roku. URL: http://zakon.rada.gov.ua/laws/show/1556-18 (data zvernennia: 15.01.2019). 5. Tymchasovyi standart vyshchoi osvity pershoho (bakalavrskoho) rivnia za haluzziu znan 07 «Upravlinnia ta administruvannia», spetsialnist 071 «Oblik i opodatkuvannia», zatv. protokolom Vchenoi Rady NUVHP № 3 vid 25.03.2016 r. 6. Tymchasovyi standart vyshchoi osvity druhoho (mahisterskoho) rivnia za haluzziu znan 07 «Upravlinnia ta administruvannia», spetsialnist 071 «Oblik i opodatkuvannia», zatv. protokolom Vchenoi Rady NUVHP № 3 vid 25.03.2016 r. 7. Pro zatverdzhennia standartu vyshchoi osvity za spetsialnistiu 071 «Oblik i opodatkuvannia» dlia pershoho (bakalavrskoho) rivnia vyshchoi osvity : nakaz Ministerstva osvity i nauky Ukrainy № 1260 vid 19.11.2018 r.

Рецензент: к.е.н., професор Зубілевич С. Я. (НУВГП) 
Pozniakovska N. M., Candidate of Engineering (Ph.D.), Associate Professor (National University of Water and Environmental Engineering, Rivne)

\section{PROFESSIONAL ACCOUNTING EDUCATION OF INTERNATIONAL STANDARTS}

The professional accountants education for International Education Standarts are researched in the article. There has been considered the main statements of accountant education for national law. Keywords: International Education Standarts, professional accountant, professional competence, technical competence, professional skills, professional values, ethics, andattitudes, practical experience.

Позняковская Н. Н., к.э.н., доцент (Национальный университет водного хозяйства и природопользования, г. Ровно)

\section{ПРОФЕССИОНАЛЬНОЕ БУХГАЛТЕРСКОЕ ОБРАЗОВАНИЕ ПО МЕЖДУНАРОДНЫМ СТАНДАРТАМ}

В статье рассматриваются вопросы обучения профессиональных бухгалтеров согласно Международным стандартам образования и основные положения бухгалтерского образования по национальному законодательству.

Ключевые слова: Международный стандарты образования, профессиональный бухгалтер, профессиональная компетентность, техническая компетентность, профессиональные навыки, профессиональные ценности, етические принципи и подходы. 